\title{
Aplikasi Media Pembelajaran Augmented Reality Pada Perangkat Keras Komputer Berbasis Android
}

\author{
Aprian Karisman*1, Fithri Wulandari ${ }^{2}$, Randy Adipraja ${ }^{3}$ \\ ${ }^{123}$ Sekolah Tinggi Teknik Multimedia Cendekia Abditama; JI. Islamic Raya Kelapa Dua, \\ Tangerang-Banten, Telp(021)5463569 \\ Program Studi Teknik Informatika, Sekolah Tinggi Teknik Multimedia Cendekia Abditama \\ e-mail:*12aprian@cendekia.ac.id, ${ }^{2}$ fithri@cendekia.ac.id, ${ }^{3}$ randyadiprajaa@gmail.com
}

\begin{abstract}
Abstrak
Dalam penulisan kali ini penulis membahas tentang perancangan pembuatan augmented reality berupa objek 3 dimensi dari perangkat keras komputer, yang dimana perangkat keras tersebut meliputi perangkat keras input, perangkat keras output, dan perangkat keras proses, tidak disitu saja perancangan di tambah dengan fitur lain seperti perakitan komputer, 12 masalah - masalah umum pada komputer (Troubleshooting), dan sistem operasi yang terdiri dari penjelasan tentang sistem operasi, cara kerja sistem operasi dan cara instalasi sistem operasi. Tujuan dari penulisan ini yaitu untuk membuat aplikasi media pembelajaran augmented reality perangkat keras komputer berbasis android yang dimana ditujukan untuk media pembelajaran tentang perangkat keras komputer yang di harapakan dari inovasi ini para pengguna bisa lebih terbantu untuk mendapatkan pembelajaran tentang perangkat keras komputer. Perangkat keras yang digunakan yaitu Google sketchup untuk pembuatan objekobjek perangkat keras dan Unity 3D untuk proses implementasi Augmented reality. Proses pembuatan Augmented reality ini melalui beberapa tahap yaitu analisis objek perangkat keras, perancangan, implementasi, dan pengujian, perancangan di buat dengan storyboard. Analisis berkaitan dengan pencarian objek-objek perangkat keras serta fungsi-fungsinya, dan alat serta perangkat yang di butuhkan dalam pembuatan Augmented reality.
\end{abstract}

Kata kunci :Augmented reality, Perangkat Keras, Vuforia, Unity $3 D$

\begin{abstract}
In this writing the author discusses the design of making augmented reality in the form of 3-dimensional objects from computer hardware, where the hardware includes input hardware, output hardware, and process hardware, not only is the design added with other features such as assembly computer, 12 common computer problems (Troubleshooting), and the operating system which consists of an explanation of the operating system, how the operating system works and how to install the operating system. The purpose of this paper is to create an augmented reality application based on android computer hardware which is intended for learning media about computer hardware which is expected from this innovation the users can be more helped to get learning about computer hardware. The hardware used is Google Sketchup for creating hardware objects and Unity $3 D$ for the Augmented reality implementation process. The process of making Augmented reality through several stages, namely hardware object analysis, design, implementation, and testing, the design is made with a storyboard. The analysis relates to the search for hardware objects and their functions, and the tools and devices needed in making Augmented reality.
\end{abstract}

Kata kunci :Augmented reality, Hardware, Vuforia, Unity 3D 


\section{PENDAHULUAN}

$P^{\prime}$ erangkat komputer adalah suatu komponen yang ada pada komputer, terdiri dari 2 jenis yaitu perangkat keras (Hardware) dan perangkat lunak (Software), disini kita fokus pada perangkat keras atau Hardware, perangkat keras pada komputer adalah bagian fisik pada komputer yang mempunyai fungsi berbeda - beda di setiap pemrosesannya, ada pun jenis dari perangkat keras yaitu, perangkat keras input yang dimana berfungsi untuk memasukan data (input) ke dalam memori sistem komputer, berikut contoh hardwareinput pada komputer yaitu keyboard, mouse, scanner. Selanjutnya perangkat keras proses yang berfungsi untuk mengolah data atau mengekseskusi suatu perintah terhadap data yang dimasukan, berikut contoh hardware porses yaitu $C P U$, Motherboard, VGA, Sound Card, dan yang terakhir adalah hardwareoutput yaitu hardware yang berfungsi untuk menampilkan atau menghasilkan keluaran dari data yang di proses, berikut contoh hardware output yaitu monitor dan speaker.

Dengan berkembangnya teknologi pada zaman sekarang, yang dimana banyak hal yang bisa di operasikan secara digital yang membuat pengguna lebih di mudahkan lagi dalam berbagai hal untuk memenehuhi kebutuhan, seperti tata cara atau tutorial mengenalkan perangkat komputer dan cara perakitan komputer secara digitalisasi, penyajian dengan tampilan yang lebih modern tentu akan lebih membuat para pengguna lebih tertarik untuk belajar tentang konten yang di berikan.

Augmented reality adalah teknologi yang menggabungkan antara benda maya ke dalam bentuk nyata tiga dimensi terhadap setiap objek yang di olah, perangkat - perangkat pada komputer nantinya akan di sajikan secara augmented reality, yang nantinya pengguna akan melihat perangkat komputer secara tiga dimensi menggunkan smartphone mereka, di tambah dengan tata cara perakitan perangkat kompuet secara tiga dimensi yang di harapkan para pengguna lebih di mudahkan mengenal perangkat komputer dan perakitan komputer secara augmented reality ini, serta di harapkan mampu memberi sensasi berbeda dalam metode pembelajaran tentang perangkat komputer ini.

Hal ini lah yang melatar belakangi penulis membuat aplikasi augmented reality perangkat keras komputer dan perakitan komputer, dengan penambahan fitur - fitur pada augmented reality yang dimana pengguna bisa melihat objek perangkat keras komputer secara tiga dimensi dan info serta fungsi dari perangkat keras komputer ini secara virtual.

\section{METODE PENELITIAN}

\subsection{Metode Pengembangan Sistem}

Pada penelitian ini metode pengembangan sistem yang digunakan adalah metode waterfall. Penulis memilih menggunakan metode pengembangan sistem waterfall pada penelitian ini karena metode ini sederhana dan cocok digunakan untuk pengembangan perangkat lunak dengan spesifikasi yang tidak berubah ubah atau kebutuhan user sudah diketahui dengan jelas. Metode air terjun atau yang sering disebut metode waterfall sering dinamakan siklus hidup klasik (classic life cycle), dimana hal ini menggambarkan pendekatan yang sistematis dan juga berurutan pada pengembangan perangkat lunak, dimulai dengan spesifikasi kebutuhan pengguna lalu berlanjut melalui tahapan-tahapanyang meliputi meliputi: analisis, perancangan, implementasi, pengujian, penerapan program, dan pemeliharaan. Namun pada penelitian ini, penulis menggunakan metode Waterfall sampai tahap pengujian.[1] 
1. Analisis Kebutuhan

Pada tahap ini, penulis mengumpulkan data yang diperlukan dari berbagai sumber melalui metode studi kepustakaan. Penulis menggunakan jaringan internet untuk mencari bahan sebagai referensi dan buku yang berhubungan.

2. Perancangan

Tahap Perancangan merupakan proses multi langkah yang berfokus pada perancangan flowcart, struktur navigasi, sketsa dan model objek.

3. Implementasi

Pada tahap ini dilakukan implementasi dengan menggabungkan objek-objek yang telah dirancang dan dimodelkan

4. Pengujian

Proses pengujian berfokus pada logika internal sistem sehingga dapat memastikan bahwa sistem sesuai dengan proses bisnis yang telah dirancang, dan fokus pada eksternal fungsional, yaitu pengujian dilakukan untuk menemukan kesalahan-kesalahan serta memastikan bahwa input yang dibatasi akan memberikan hasil aktual sesuai dengan hasil yang dibutuhkan.

5. Evaluasi

Pada tahap ini dilakukan untuk melihat keberhasilan dari aplikasi yang dibangun dengan cara menyebarkan angket/ kuesioner.

\subsection{Studi Pustaka}

Ada beberapa penelitian mengenai pengembangan media pengajaran dengan memanfaatkan teknologi augmented reality. Salah satunya adalah penelitian pada tahun 2017 dengan judul "Pengembangan Media Pembelajaran Berbasis Augmented reality". Pada penelitian tersebut, peneliti merancang dan membuat aplikasi media pembelajaran dengan menggunakan teknologi augmented reality. Berdasarkan hasil penelitian tersebut dapat disimpulkan bahwa dengan pemanfaatan augmented reality, guru dapat membuat media pembelajaran yang menyenangkan, interaktif, dan mudah digunakan.Augmented reality juga dapat menggantikan modul pembelajaran yang belum ada di sekolah dalam bentuk virtual atau maya. Siswa tetap dapat melihat dan menggunakan modul seperti modul aslinya, namun dalam bentuk virtual.[2]

Penelitian selanjutnya yaitu penelitian dengan judul "Pengembangan Media Edukatif Berbasis Augmented reality untuk Desain Interior dan Eksterior". Berdasarkan hasil penelitian tersebut dapat disimpulkan bahwa media edukatif berbasis augmented reality sangat layak untuk digunakan dalam pembelajaran desain interior dan eksterior dikarenakan sudah divalidasi oleh para ahli dan diimplementasikan di kelas dan media edukatif desain interior dan eksterior berbasis augmented realityefektif untuk digunakan pembelajaran. Kefektifan terlihat dari adanya peningkatan hasil belajar kelas eksperimen lebih tinggi dibandingkan dengan kelas kontrol. [3]

Ada juga penelitian dengan judul "Pengembangan Media Pembelajaran Berbasis Augmented reality Pengenalan Komponen Sistem Kendali Elektromagnetik". Penelitian tersebut menghasilkan media pembelajaran berbasis augmented reality tentang pengenalan komponen sistem kendali elektromagnetik dan menyimpulkan bahwa media pembelajaran berbasis

Karisman, et.al (Aplikasi Media Pembelajaran Augmented Reality Pada Perangkat Keras Komputer Berbasis Android) 
augmented reality dapat membantu pemahaman siswa sehingga dapat digunakan oleh guru pengampu dalam kegiatan pembelajaran.[4]

Dari penelitian-penelitian di atas dapat disimpulkan bahwa penerapan teknologi augmented realitypada aplikasimedia pembelajaran dapat membantu dalam proses pengajaran, terutama dalam memvisualisasikan materi-materi ajar yang perlu untuk digambarkan secara visual. Oleh karena itu, peneliti tertarik untuk mengembangkan media pembelajaran perangkat keras komputer dengan memanfaatkan teknologi augmented reality.

\subsubsection{Augmented Reality}

Realitas tertambah, atau dikenal dengan singkatan bahasa Inggrisnya AR (augmented reality), adalah teknologi yang menggabungakan benda maya dua dimensi dan ataupun tiga diemensi kedalam sebuah lingkungannya tiga dimensi lalu memproyeksikan benda -benda maya tersebut dalam waktu nyata. Tidak seperti realitas maya yang sepenuhnya menggantikan kenyataan, realitas tertambah sekadar menambahkan atau melengkapi kenyataan. Benda-benda maya menampilkan informasi yang tidak dapat diterima oleh pengguna dengan inderanya sendiri. Hal ini membuat realita serta tambah sesuai sebagai alat untuk membantu persepsi dan interaksi penggunanya dengan dunia nyata. Informasi yang ditampilkan oleh benda maya membantu pengguna melaksanakan kegiatan-kegiatan dalam dunia nyata. Augmented reality adalah sebagai penggabungan benda-benda nyata dan maya dilingkungan nyata, berjalan secara interaktif dalam waktu nyata, dan terdapat integrasi antar benda dalam tiga dimensi, yaitu benda maya terintegrasi dalam dunia nyata. Penggabungan benda nyata dan maya dimungkinkan dengan teknologi tampilan yang sesuai, interaktivitas dimungkinkan melalui perangkatperangkat input tertentu, dan integrasi yang baik memerlukan penjejakan yang efektif. [5]

\subsubsection{Prinsip Kerja Augmented Reality}

Sistem Augmented reality bekerja berdasarkan deteksi citra dan citra yang digunakan adalah marker. Augmented reality merupakan integrasi elemen-elemen digital yang ditambahkan kedalam dunia nyata secara realtime dan mengikuti keadaan lingkungan yang ada di dunia nyata. Berdasarkan Gambar 1, berikut prinsip kerja augmented reality: Camera yang telah dikalibrasi akan mendeteksi marker yang diberikan, kemudian setelah mengenali dan menandai pola marker, webcam akan melakukan perhitungan apakah marker sesuai dengan database yang dimiliki. Bila tidak, maka informasi marker tidak akan diolah, tetapi bila sesuai maka informasi marker akan digunakan untuk me-render dan menampilkan objek 3D atau animasi yang telah dibuat sebelumnya. [6] 


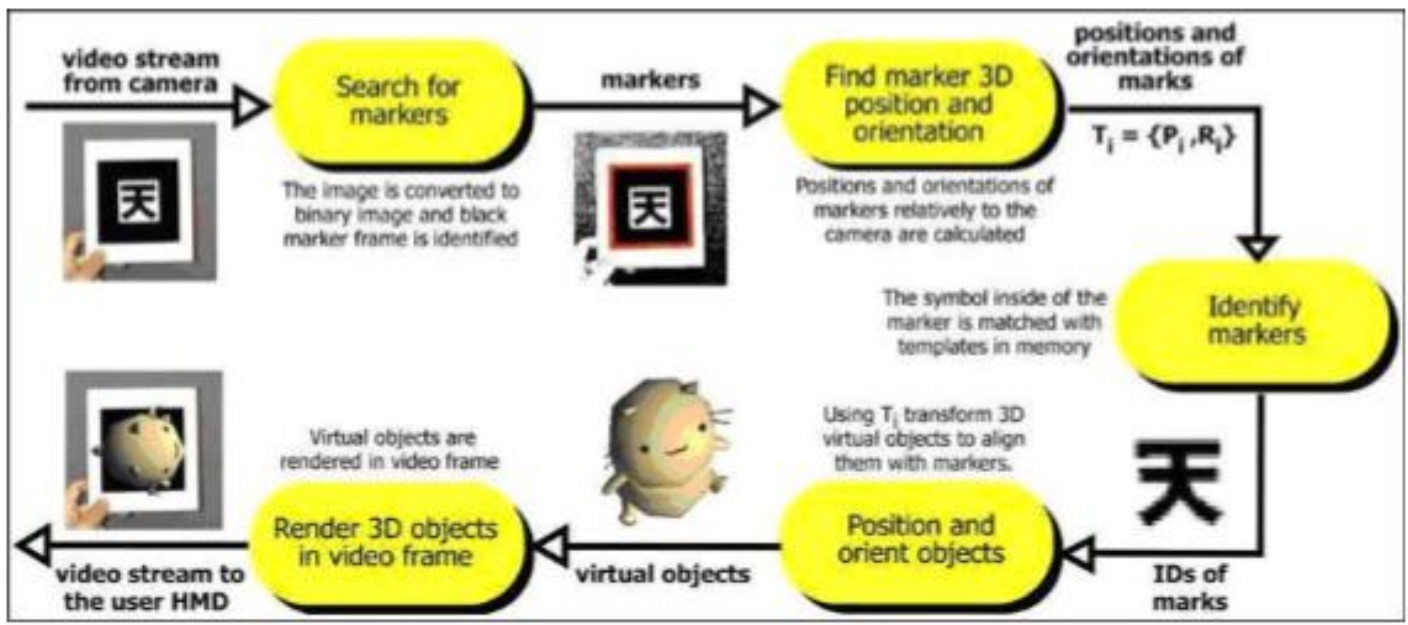

Gambar 1. Prinsip Kerja Augmented Reality [6]

\subsubsection{Unity $3 D$}

Unity $3 D$ adalah sebuah alat yang digunakan untuk membuat games, simulasi, dan bangunan arsitektur. Unity dapat diterapkan untuk game PC dan Game online memakai unity browser. Pemrograman yang digunakan bervariasi, antara lain JavaScript, C\#, dan Boo. Unity adalah sebuah game multiplatform yang dapat digunakan pada PC, Mac, Wii, iPhone, iPad, Android dan browser. Perizinan atau license dariUnity ada dua bentuk. Ada Unity dan Unity Pro. Versi Unity tersedia dalam bentuk gratis, sedang versi Unity Pro hanya dapat dibeli. Versi Unity pro ada dengan fitur bawaan seperti efek post processing dan renderefektexture. Versi Unity merupakan yang gratis memperlihatkan aliran untuk game web dan layar splash untuk game yang berdiri sendiri. Unity dan Unity Pro menyediakan tutorial, isi, contoh project, wiki, dukungan melalui forum dan perbaruan kedepannya. Unitydigunakan pada iPhone, iPod dan iPad operating system yang mana $i O S$ ada sebagai add-ons pada Unity editor yang telah ada lisensinya, dengan cara yang sama juga pada Android. [7]

\subsubsection{Vuforia Qualcomm}

Vuforia Qualcomm merupakan library yang digunakan sebagai pendukung adanya augmented reality pada Android. Vuforia menganalisa gambar dengan menggunakan pendeteksi marker dan menghasilkan informasi 3D dari marker yang sudah dideteksi via API. Programmer juga dapat menggunakannya untuk membangun objek 3D virtual pada kamera. Vuforia mengijinkan pengembang untuk melakukan koneksi antara aplikasi yang sudah dibuat dengan library static contohnya libQCAR.a pada $i O S$ atau libQCAR.so pada Android. Gambar 2 menjelaskan gambaran umum bagaimana proses pembangunan aplikasi mengunakan vuforia. User meng-upload gambar masukan untuk target yang ingin dilacak dan diregistrasikan. Kemudian mendownload sumberdaya target yang di-bundel pada aplikasi. Pada proses ini sumberdaya target yang didowload yaitu berupa library yang sudah di-bundel dengan aplikasi unity $3 D$. [8] 


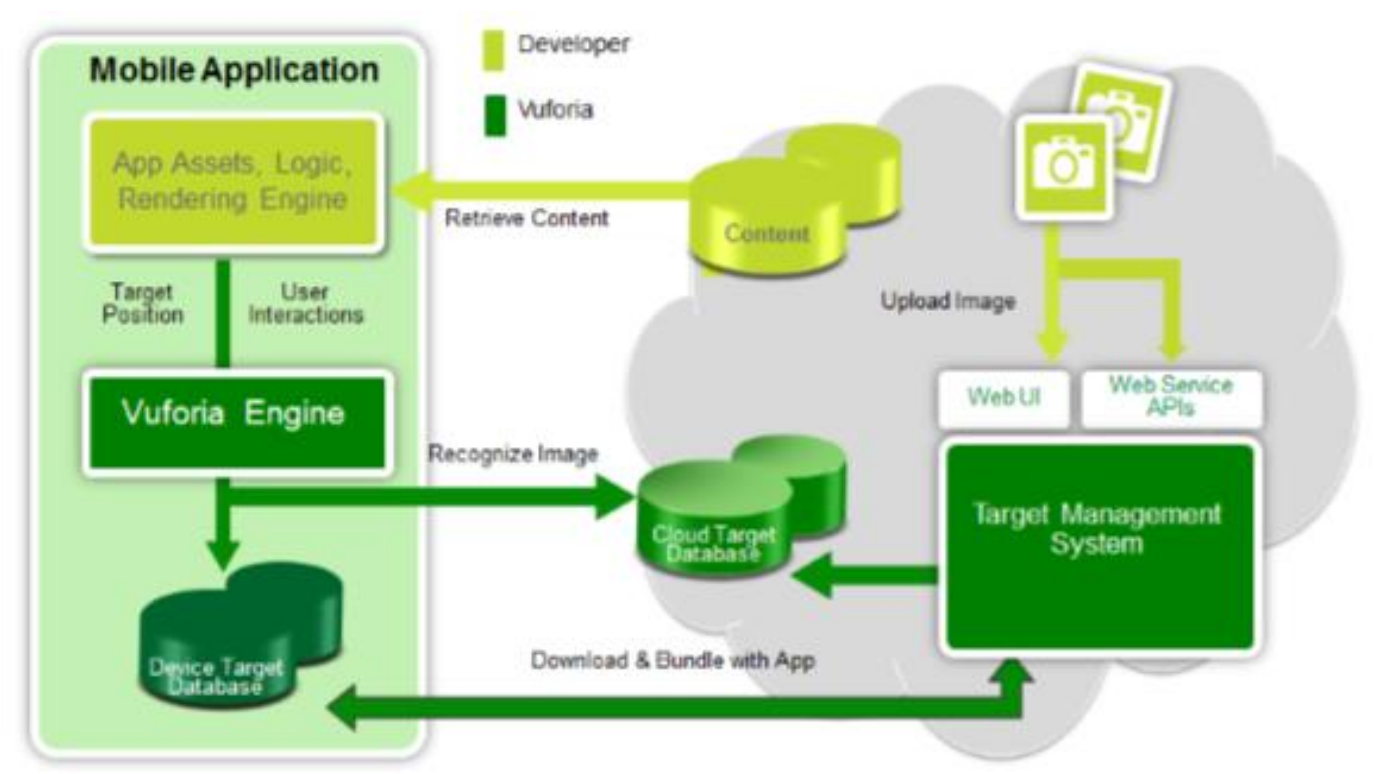

Gambar 2. Proses Pembangunan Aplikasi Mengunakan Vuforia [8]

\section{HASIL DAN PEMBAHASAN}

\subsubsection{Analisis kebutuhan}

Analisis berkaitan dengan pencarian objek-objek perangkat keras serta fungsifungsinya, dan alat serta perangkat yang di butuhkan dalam pembuatan Augmented reality.

\subsubsection{Perancangan}

Pertama - pertama untuk perancangan di buat terlebih dahulu flowchart untuk tumpuan perancangan aplikasi. 


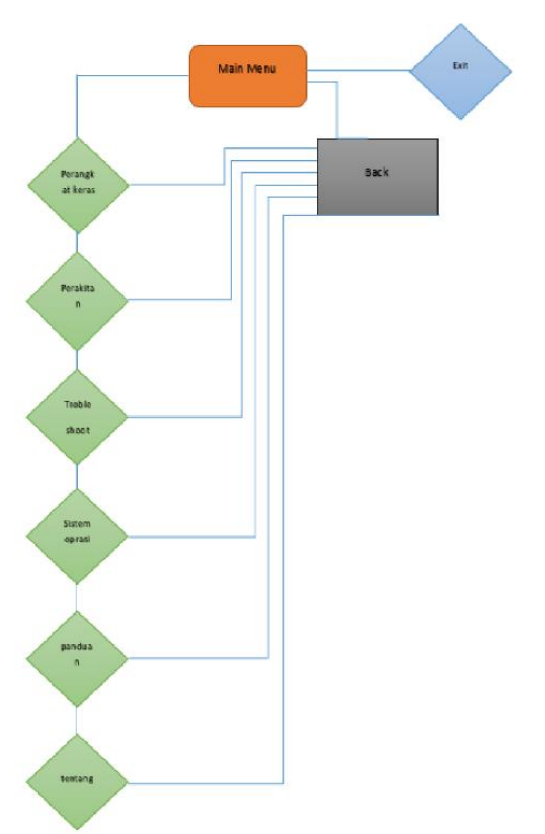

Gambar 3. Flowchart

Selanjutnya pembuatan struktur navigasi yang dimana digunakan untuk pemodelan setiap tombol pada aplikasi jika di tekan.

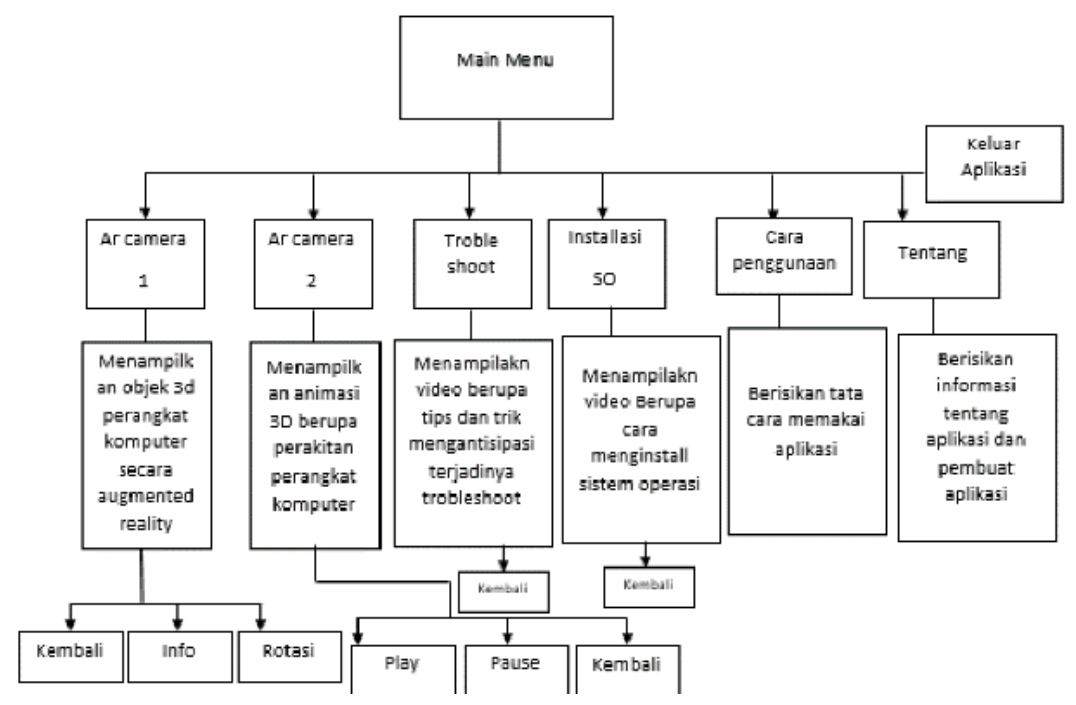

Gambar 4. Struktur Navigasi

Selanjutnya pembuatan storyboard untuk alur jalannya crita aplikasi. 


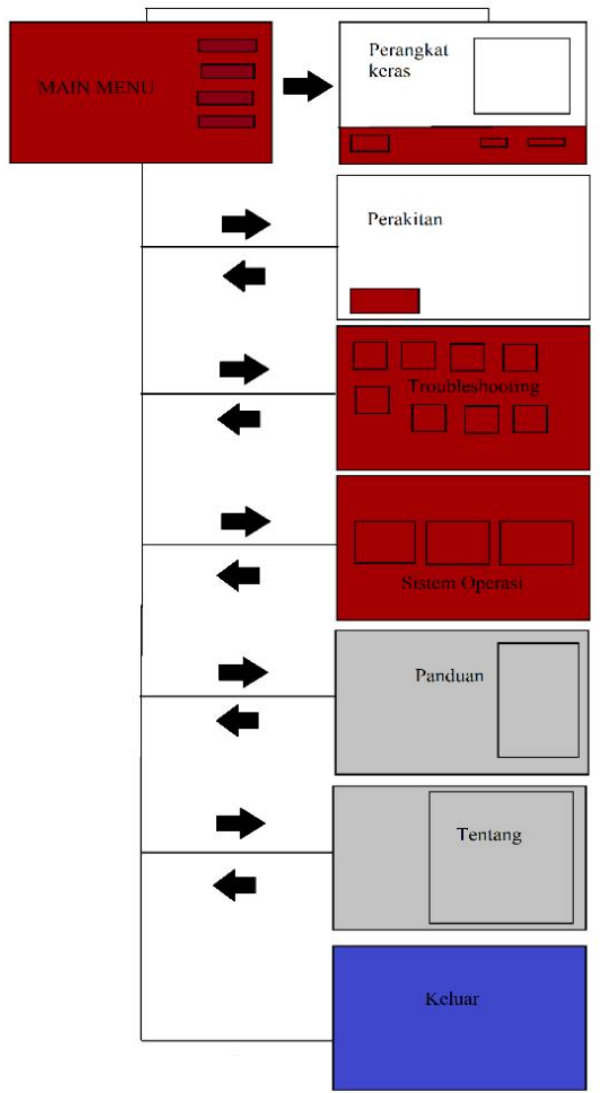

Gambar 5. Storyboard

\subsubsection{Perancangan Model 3D Objek}

Perancangan model ini meiputi perancangan setiap objek pada aplikasi berupa 21 model objek perangkat keras yang dimana di rancang pada aplikasi google sketchup. Berikut sempel dari perancangan model 3d di google sketchup :

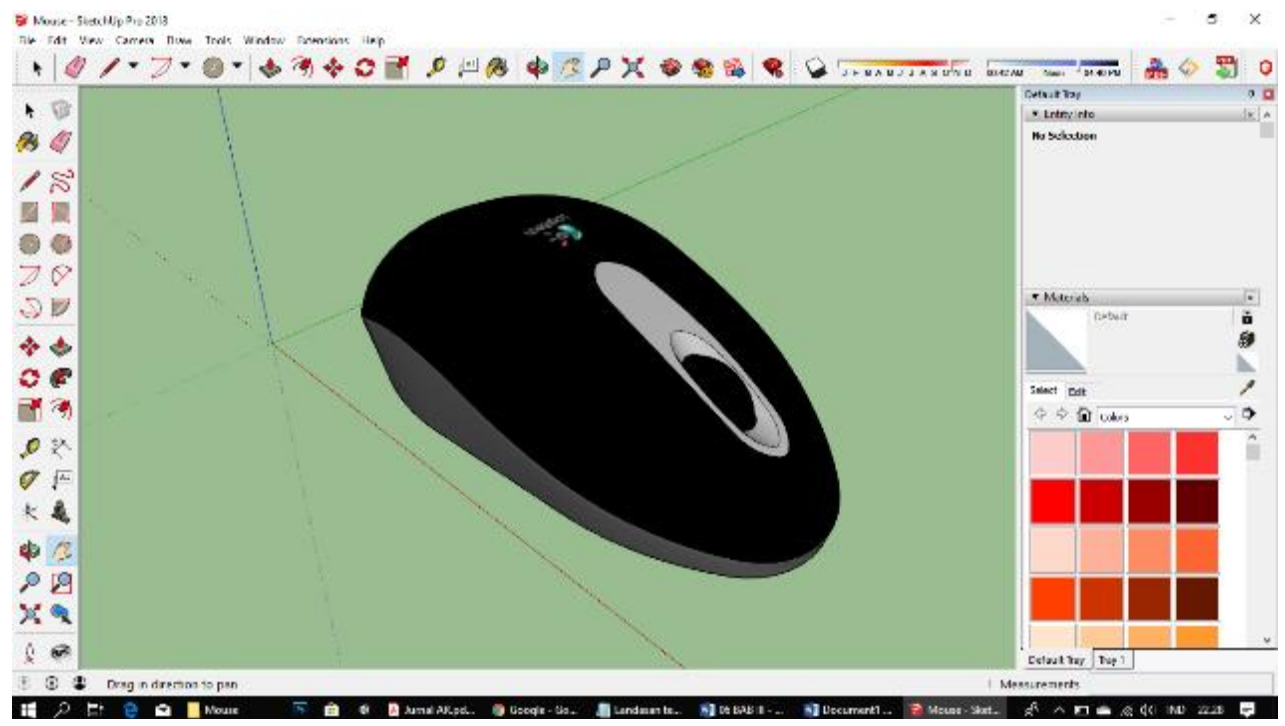

Gambar 6. Rancangan Model 3d di Google sketchup

Karisman, et.al (Aplikasi Media Pembelajaran Augmented Reality Pada Perangkat Keras Komputer Berbasis Android) 


\subsubsection{Perancangan Sketsa Interface}

Perancangan selanjutnya yaitu merancang sketsa pemodelan interface untuk di implementasiakan pada proses perancangan di Unity $3 \mathrm{~d}$ nantinya mengikuti alur dari storyboard.Berikut sempelperancangan sketsa interface :

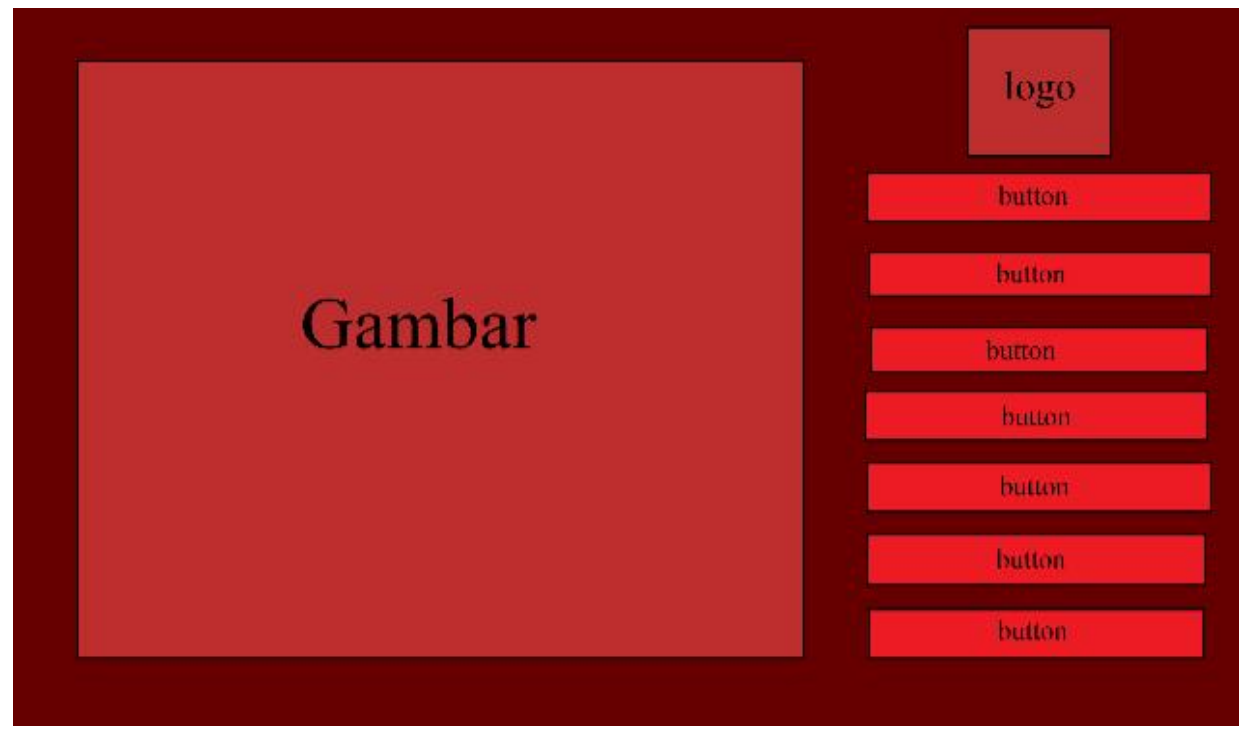

Gambar 7. Sketsa Interface Aplikasi

\subsection{Implementasi}

Pada tahap ini terjadi proses perancangan dari objek $3 \mathrm{~d}$ google sketchup di import pada unity 3d untuk proses pembuatan augmented reality serta membuat interface dari sketsa interface yang telah di buat. Pada tahap ini, seluruh model objek $3 \mathrm{~d}$ di import ke unity $3 \mathrm{~d}$ serta perancangan interface di setiap scenenya.Berikut sempel implementasi aplikasi :

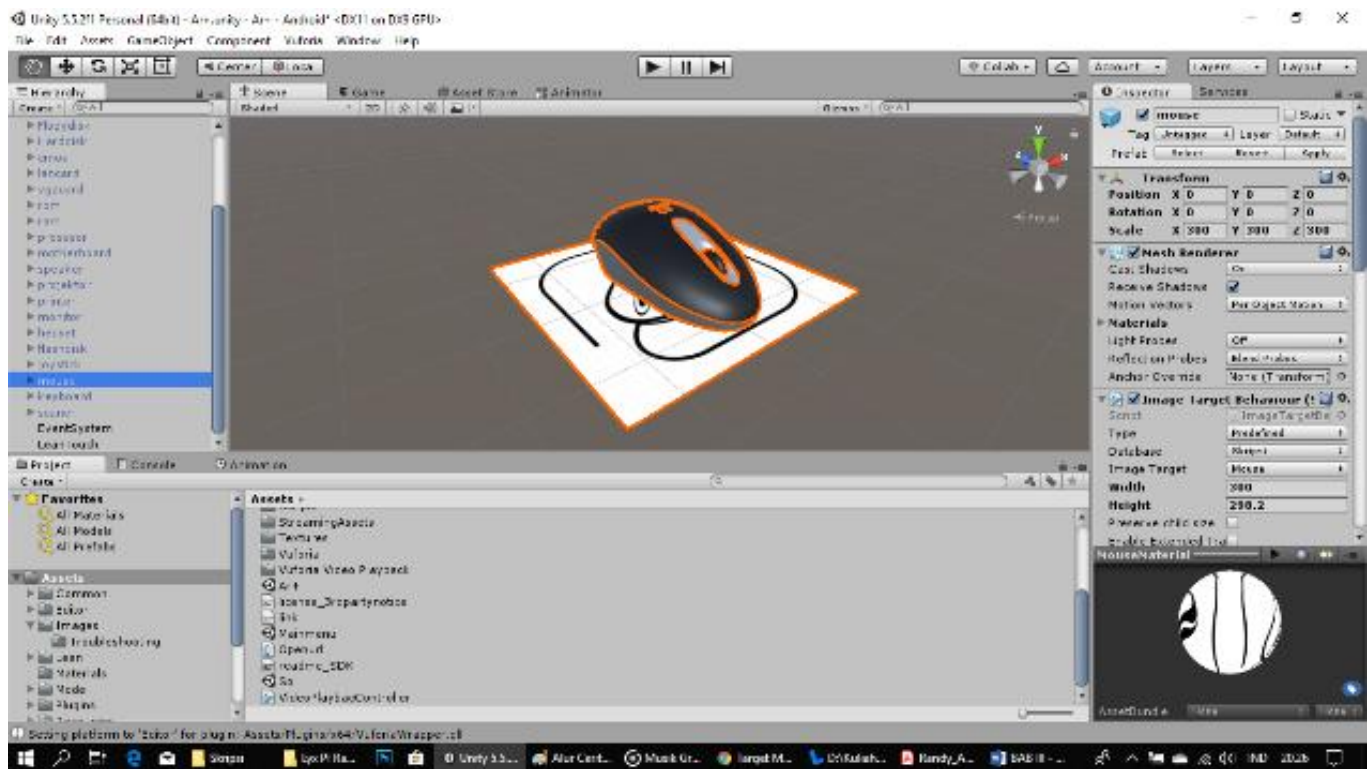

Gambar 8. Implementasi Objek 3d di unity

Karisman, et.al (Aplikasi Media Pembelajaran Augmented Reality Pada Perangkat Keras Komputer Berbasis Android) 


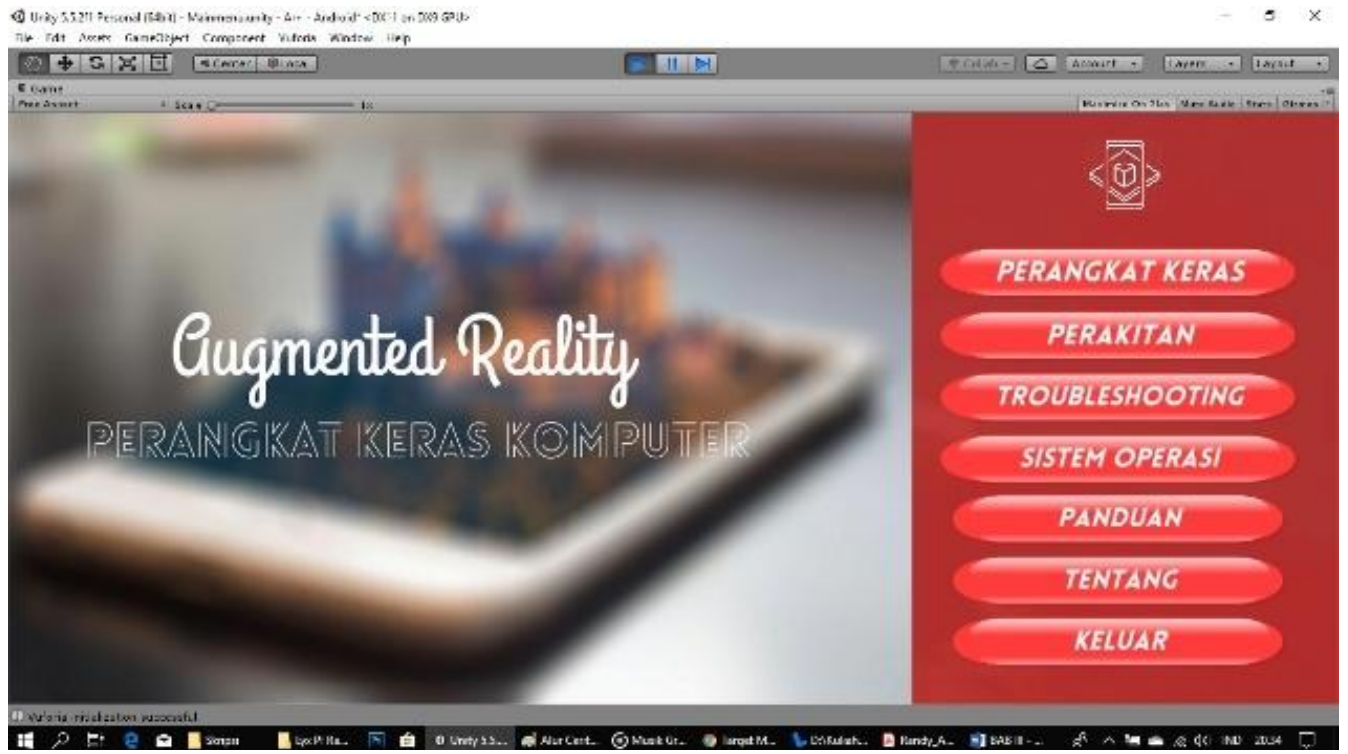

Gambar 9. Implementasi interface

\subsection{Pengujian}

Masuk pada tahap pengujian untuk pertama kali, pengujian di lakukan pada smartphone Realme 2 Pro dengan sistem operasi Android Pie 9.0.Pada tahapan kali ini dimana masuk pada tahap pengujian yang dimana pengujian di lakukan dengan metode black box testing. Black box testing adalah suatu pengujian yang dilakukan untuk mengamati hasil dari eksekusi pada software tersebut.

\subsubsection{Hasil Pengujian}

Beriskan tabel hasil dari pengujian yang sudah di lakukan pada rencana pengujian. Akan di tampilkan pada table berikut:

Tabel 1. Hasil Pengujian

\begin{tabular}{|l|l|l|l|}
\hline Test Case & Hasil yang di harapkan & Hasil yang di dapatkan & keterangan \\
\hline $\begin{array}{l}\text { Instalasi } \\
\text { apliksai }\end{array}$ & $\begin{array}{l}\text { Berhasil terinstal dengan baik } \\
\text { pada sistem operasi Lolipop } \\
\text { sampai Pie. }\end{array}$ & $\begin{array}{l}\text { Berhasil terinstal di sistem } \\
\text { operasi pie, Oreo, dan Kitkat. }\end{array}$ & Berhasil \\
\hline $\begin{array}{l}\text { Perangkat } \\
\text { keras }\end{array}$ & $\begin{array}{l}\text { Berhasil menampilkan objek } \\
\text { pada marker, serta deskripsinya. } \\
\text { Tombol-tombol berfungsi degan } \\
\text { baik. }\end{array}$ & $\begin{array}{l}\text { Berhasil berjalan dengan apa } \\
\text { yang di harapkan. }\end{array}$ & Berhasil \\
\hline Perakitan & $\begin{array}{l}\text { Berhasil menjalankan video } \\
\text { yang ada di dalmnya dan proses } \\
\text { scale berjalan. }\end{array}$ & $\begin{array}{l}\text { Berhasil berjalan dengan apa } \\
\text { yang di harapkan. }\end{array}$ & Berhasil \\
\hline $\begin{array}{l}\text { Troublesh } \\
\text { ooting }\end{array}$ & $\begin{array}{l}\text { Berhasil menjalankan 12 12 } \\
\text { tombol yang ada di alanya serta } \\
\text { berhasil membuka beberapa } \\
\text { video yang terdapat di di dengan apa } \\
\text { dalamnya. }\end{array}$ & $\begin{array}{l}\text { Berhasil sesuai dengangan diharapkan seperti } \\
\text { yang } \\
\text { membuka setiap halaman dan } \\
\text { video. }\end{array}$ & \\
\hline
\end{tabular}

Karisman, et.al (Aplikasi Media Pembelajaran Augmented Reality Pada Perangkat Keras Komputer Berbasis Android) 


\begin{tabular}{|l|l|l|l|}
\hline Sistem \\
operasi & $\begin{array}{l}\text { Berhasil membuka halaman } \\
\text { penjelasan sstem operasi dan } \\
\text { video yang terdapat pada tombol } \\
\text { cara kerja sistem operasi dan } \\
\text { instalasi sistem operasi }\end{array}$ & $\begin{array}{l}\text { Semua Berhasil berjalan } \\
\text { dengan baik sesuai dengan } \\
\text { yang di harapkan }\end{array}$ & Berhasil \\
\hline Panduan & $\begin{array}{l}\text { Berhasil mebuka halaman } \\
\text { panduan serta tombol back yang } \\
\text { ada di dalamnya }\end{array}$ & $\begin{array}{l}\text { Berhasil berjalan dengan apa } \\
\text { yang di harapkan. }\end{array}$ & Berhasil \\
\hline Tentang & $\begin{array}{l}\text { Berhasil mebuka halaman } \\
\text { panduan serta tombol back yang } \\
\text { ada di dalamna }\end{array}$ & $\begin{array}{l}\text { Berhasil berjalan dengan apa } \\
\text { yang di harapkan. }\end{array}$ & Berhasil \\
\hline Keluar & $\begin{array}{l}\text { Berhasil keluar aplikasi } \\
\text { Pengujian berjalan dengan } \\
\text { baik }\end{array}$ & Berhasil. \\
\hline
\end{tabular}

\subsection{Evaluasi}

Pada tahap ini pengujian sudah di nyatakan berhasil dan masuk pada tahap evaluasi yang dimana mengevaluasikan aplikasi kepada responden yaitu dengan metode pembagian angket atau kuesiner.

Kuesioner pada aplikasi ini mempunyai 6 pertanyaan yang masing - masing akan di beri point yang nantnya akan di di ajukan pada setiap responden, berikut 6 pertanyaannya :

1. Apakah aplikasi ini membantu anda untuk belajar Perangkat keras komputer ?

2. Apakah hasilnya sesuai dengan yang anda butuhkan tentang perangkat keras komoputer?

3. Apakah aplikasi ini mudah untuk di gunakan ?

4. Desain dari aplikasi ini menarik ?

5. Pada saat anda menggunakan aplikasi sejauh mana anda menguasai aplikasi ini ?

6. Menurut anda bagaimana hasil dari keseluruhan aplikasi ?

Yang dimana mempunyai 5 opsi beserta pointnya seperti berikut :

- SS : Sangat setuju $=4$ point

- $\mathrm{S}:$ Setuju $=3$ point.

- KS : Kurang setuju $=2$

- TS : Tidak setuju = 1

- STS : Sangat tidak setuju $=0$

Cara kerja kuesioner:

Memiliki 6 pertanyaan yang di bagikan kepada 30 responden. jika setiap pertanyaan mendapatkan nilai 60 sampai 100 point maka di nyatakan berhasil jika pertanyaan di bawah 60 maka dinyatakan tidak berhasil. Berikut Diagram hasil kuesioner yang telah dilakukan. 


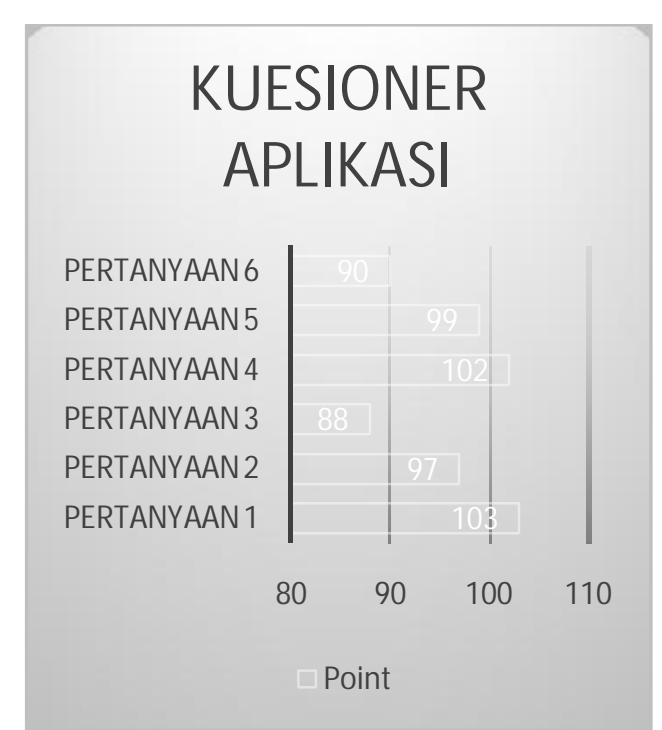

Gambar 8. Hasil Diagram Kuesioner

Keterangan diagram kuesioner :

- Pertanyaan 1 mndapatkan nilai 103 maka di nyatakan berhasil.

- Pertanyaan 2 mndapatkan nilai 97 maka di nyatakan berhasil.

- Pertanyaan 3 mndapatkan nilai 88 maka di nyatakan berhasil.

- Pertanyaan 4 mndapatkan nilai 102 maka di nyatakan berhasil.

- Pertanyaan 5 mndapatkan nilai 99 maka di nyatakan berhasil.

- Pertanyaan 6 mndapatkan nilai 90 maka di nyatakan berhasil.

\section{KESIMPULAN}

Keseluruhan perancangan sampai implementasi aplikasi berjalan dengan baik seperti apa yang di harapkan. Berdasarkan hasil pengujian aplikasi dengan metode black box hasil yang di dapatkan menyatakan bahwa aplikasi berhasil berjalan dengan baik. Dan dalam tahap evaluasi dengan memberi angket atau kuesioner kepada responden mendapatkan hasil $90 \%$ menyatakan bahwa responden mendapatkan informasi yang tersaji tentang perangkat keras komputer. Dan dapat disimpulkan bahwa aplikasi pembelajaran ini sangatinteraktif dan mudahdigunakan, sehinggadengan mengaplikasikan aplikasi media pembelajaran ini dapat membantu meningkatkan proses pengajaranyang lebihmenarik dan mudahdipahami.

\section{SARAN}

Adapun saran untuk penegembangan aplikasi yaitu, penambahan animasi 3 dimensi untuk tutorial perakitan komputer, serta penambahan efek pada objek agar terlihat lebih realistik. 


\section{DAFTAR PUSTAKA}

[1]E. D. Nurmawan, Mulyati. 2019, Sistem Informasi Kepegawaian Berbasis Website pada PT Sumatera Panca Rajo Palembang, Jurnal Teknik Informatika dan Sistem Informasi, eISSN:2503-2933, Vol. 5, No. 2.

[2] I. Mustaqin, N. Kurniawan, 2017, Pengembangan Media Pembelajaran Berbasis Augmented reality, Jurnal Edukasi Elektro, e-ISSN : 2548-8260, Vol. 1, No. 1.

[3]A. M. W. Wahyudi, H. Wibawanto. 2017, Pengembangan Media Edukatif Berbasis Augmented Reality untuk Desain Interior dan Eksterior, Innovative Journal of Curriculum and Educational Technology, IJCET 6 (2), Hal. 98 - 107.

[4]Hamalik, Oemar. 2001, Perencanaan Pengajaran Pendekatan Sistem, Bumi Aksara, Bandung.

[5] R. T. Azuma. 1997, A Survey of Augmented Reality, Hughes Research Laboratories.

[6] R. T. Azuma. 2001, Teleoperators and Virtual Environments, A Survey of Augmented Reality, Presence.

[7] Mario Fernando. 2013, Membuat Aplikasi Android Augmented Reality Menggunakan Vuforiasdk dan Unity, AR Online, Surakarta.

[8]Hynra. 2014, Unity Tutorial Vuforia Simple Image Target, Unity Tutorial, https://hynra.com/post/unity-tutorial-vuforia-simple-image-target, Diakses tanggal 27 Juli 2019. 